\title{
Olive cultivation in the heart of the Persian Achaemenid Empire: new insights into agricultural practices and environmental changes reflected in a late Holocene pollen record from Lake Parishan, SW Iran
}

\author{
Morteza Djamali $^{1,2} \cdot$ Matthew D. Jones $^{3} \cdot$ Jérémy Migliore $^{1} \cdot$ Silvia Balatti $^{4}$ • \\ Marianela Fader ${ }^{1} \cdot$ Daniel Contreras $^{1} \cdot$ Sébastien Gondet $^{5} \cdot$ Zahra Hosseini $^{1}$. \\ Hamid Lahijani $^{2}$ - Abdolmajid Naderi ${ }^{2}$ - Lyudmila S. Shumilovskikh ${ }^{1}$ • \\ Margareta Tengberg6 ${ }^{6}$ Lloyd Weeks ${ }^{7}$ \\ Received: 6 February 2015/ Accepted: 3 August 2015
}

\begin{abstract}
Ancient Persia witnessed one of its most prosperous cultural and socio-economic periods between $550 \mathrm{BC}$ and $\mathrm{AD}$ 651, with the successive domination of the Achaemenid, Seleucid, Parthian and Sassanian Empires. During this period agricultural activities increased on the Iranian plateau, as demonstrated by a remarkable arboricultural expansion. However, available data are not very informative about the spatial organization of agricultural practices. The possible links between climate conditions and agricultural activities during this millennium of continuous imperial domination are also unclear, due to the lack of parallel human-independent palaeoclimatic proxies. This study presents a new late Holocene pollen-based vegetation record from Lake Parishan, SW Iran. This record provides invaluable information regarding anthropogenic activities before, during and after the empires and
\end{abstract}

Communicated by A. Fairbairn.

Morteza Djamali

morteza.djamali@imbe.fr

1 Institut Méditerranéen de Biodiversité et d'Ecologie (IMBE) UMR CNRS 7263/IRD 237/Aix-Marseille Université/ Avignon Université, Technopôle de l'Environnement ArboisMéditerranée, BP 80, 13545 Aix-en-Provence Cedex 04, France

2 Iranian National Institute for Oceanography and Atmospheric Sciences (INIOAS), No. 9 Etemad Zadeh St., West Fatemi Ave, Tehran 14155-4781, Iran

3 School of Geography, University of Nottingham, University Park, Nottingham NG7 2RD, UK

4 Graduate School "Human Development in Landscapes" and Institut für Klassische Altertumskunde, Christian-AlbrechtsUniversität zu Kiel, Leibnizstraße 3, Room 138, 24118 Kiel, Germany sheds light on (i) spatial patterning in agricultural activities and (ii) possible climate impacts on agro-sylvo-pastoral practices during this period. Results of this study indicate that arboriculture was the most prominent form of agricultural activity in SW Iran especially during the Achaemenid, Seleucid and Parthian periods. Contrary to the information provided by some Greco-Roman written sources, the record from Lake Parishan shows that olive cultivation was practiced during Achaemenid and Seleucid times, when olive cultivation was significant, at least in this basin located close to the capital area of the Achaemenid Empire. In addition, pollen from aquatic vegetation suggests that the period of the latter centuries of the first millennium $\mathrm{BC}$ was characterized by a higher lake level, which might have favoured cultural and socio-economic prosperity.

5 UMR 5133 Archéorient (CNRS, Université Lyon 2), Maison de l'Orient et de la Méditerranée, 5-7 rue Raulin, 69365 Lyon Cedex 7, France

6 Laboratoire d'Archéozoologie et Archéobotanique, UMR 7209 CNRS, Département Ecologie et Gestion de la Biodiversité, Muséum National d'Histoire Naturelle (MNHN), 55 rue Buffon, 75005 Paris, France

7 School of Humanities, University of New England, Armidale, NSW 2351, Australia 
Keywords Tree cultivation $\cdot$ Dodonaea Socioeconomic changes $\cdot$ Climate change $\cdot$ Zagros $\cdot$ Middle East

\section{Introduction}

Arboriculture is an advanced form of agriculture developed long after the beginning of cereal cultivation, one which marks the establishment of the fully sedentary lifestyle (Bottema and Woldring 1990; Zohary and Hopf 1994). In the continental Middle East, the period corresponding to the successive Achaemenid, Seleucid, Parthian and Sassanian empires (550 BC-AD 642) possibly witnessed one of the most remarkable periods of agricultural activities in ancient Iran (Djamali et al. 2011). During the Achaemenid Empire (550-330 BC), a regional expansion of arboriculture occurred in the southern Zagros, on such a scale that arboriculture has not since antiquity reached this apogee again (Djamali et al. 2009a, 2011). At the same time, some pollen data indicate the expansion of cereal cultivation in the highland regions of NW Iran (Djamali et al. 2009b). However, in the heartland of Persia in the southern Zagros Mountains, most of our data on regional arboricultural practices are based on a single pollen diagram from Lake Maharlou, $50 \mathrm{~km}$ to the south of the Persepolis. This diagram suggests that at least walnut (Juglans), grapevine (Vitis), and plane tree (Platanus) were among the main cultivated tree species (Djamali et al. 2009a). Olive cultivation was suggested with great caution because of the possibility of olive pollen coming from distant sources or wild olive stands found in the Saharo-Sindian region of southern Iran (Djamali et al. 2009a). Some of these trees may have been introduced from Anatolia and the Balkans, where a remarkable phase of tree cultivation ('Beyşehir Occupation phase') has been reported from $\sim 3,600$ to $\sim 3,400 \mathrm{cal}$ BP during the Bronze Age (Bottema and Woldring 1990; Eastwood et al. 1998). The phylogeography of the olive tree suggests that the cradle of primary domestication was the northeastern Levant, from which the olive spread through a long and continuous process of dissemination that involved numerous genetic exchanges between the cultivated trees and wild gene pools (Besnard et al. 2013).

This study presents new pollen data from Lake Parishan, located $\sim 100 \mathrm{~km}$ to the west of Lake Maharlou (Fig. 1). The agricultural activities reflected in this new pollen diagram allow a comparison between these two records to be made, and enable better understanding of the spatiotemporal context of arboricultural activities in ancient Persia. Lake Parishan ( $~ 823 \mathrm{~m}$ a.s.l.) lies within a small catchment basin, the Kazeroun plain, located 600 m below
Lake Maharlou ( $\sim 1,450 \mathrm{~m}$ a.s.l.) and as a consequence is surrounded by different vegetation types. The presented pollen diagram provides not only new insights into human activities which are poorly known in the Lake Parishan basin, but also helps to reconstruct changes in lake level, which provide wider palaeoenvironmental information for this time period.

\section{Setting}

\section{The wetland}

Lake Parishan $\left(51^{\circ} 44^{\prime}-51^{\circ} 54^{\prime} \mathrm{E}, 29^{\circ} 27^{\prime}-29^{\circ} 33^{\prime} \mathrm{N}\right.$; $823 \mathrm{~m}$ a.s.l.) is a shallow, freshwater to brackish lake located about $15 \mathrm{~km}$ to the east of the town of Kazeroun, Fars Province, SW Iran, within a closed intermountain basin dominated by intensively karstified Mesozoic and Cenozoic limestone formations. Lake Parishan is a Wetland of International Importance, registered under the Ramsar Convention (no. 37 on 23/06/1975). Water depths normally vary between a few $\mathrm{cm}$ in the southern, eastern, and western parts to about $4 \mathrm{~m}$ in the northern part of the lake (see below for further details). Based on the MedWet Habitat Description System, the Lake Parishan ecosystem can be divided into two major systems: (i) 'lacustrine system' defined as the main water body permanently or semi-permanently inundated with water bearing little or no emergent vegetation and (ii) 'palustrine system' defined as those areas with emergent vegetation which are most often seasonally inundated and mostly found in southwestern and eastern parts of the lake (UNDP/GEF 2008).

\section{Climate and hydrology}

The Lake Parishan region has an intermediate bioclimate between: (i) the pluviseasonal to xeric continental Mediterranean bioclimates that dominate the Zagros highlands and (ii) the tropical xeric/desertic bioclimates of the Mesopotamian plains and Persian Gulf area (Djamali et al. 2012). According to the mean values of the Kazeroun (15 km west of the lake) meteorological stations (data from Iran Meteorological Organization), mean annual precipitation is about $357 \mathrm{~mm}$, mainly falling from November to April followed by a dry season lasting from June to September. Mean annual temperature is $22.9^{\circ} \mathrm{C}$ and the mean values of coldest and hottest months of the year are 9.9 and $33.9^{\circ} \mathrm{C}$, respectively. Although storm tracks originating from the Mediterranean Sea and North Atlantic Ocean bring moisture to southern Zagros (Stevens et al. 
Fig. 1 Sketch map of the Parishan wetland and its surrounding lands with the position of the study core (LPIII). Climate diagrams of Shiraz ( $\mathrm{S}$ in the inset map), Kazeroun, and Borazjan (B in the inset map) are based on data released by Iran Meteorological Organization

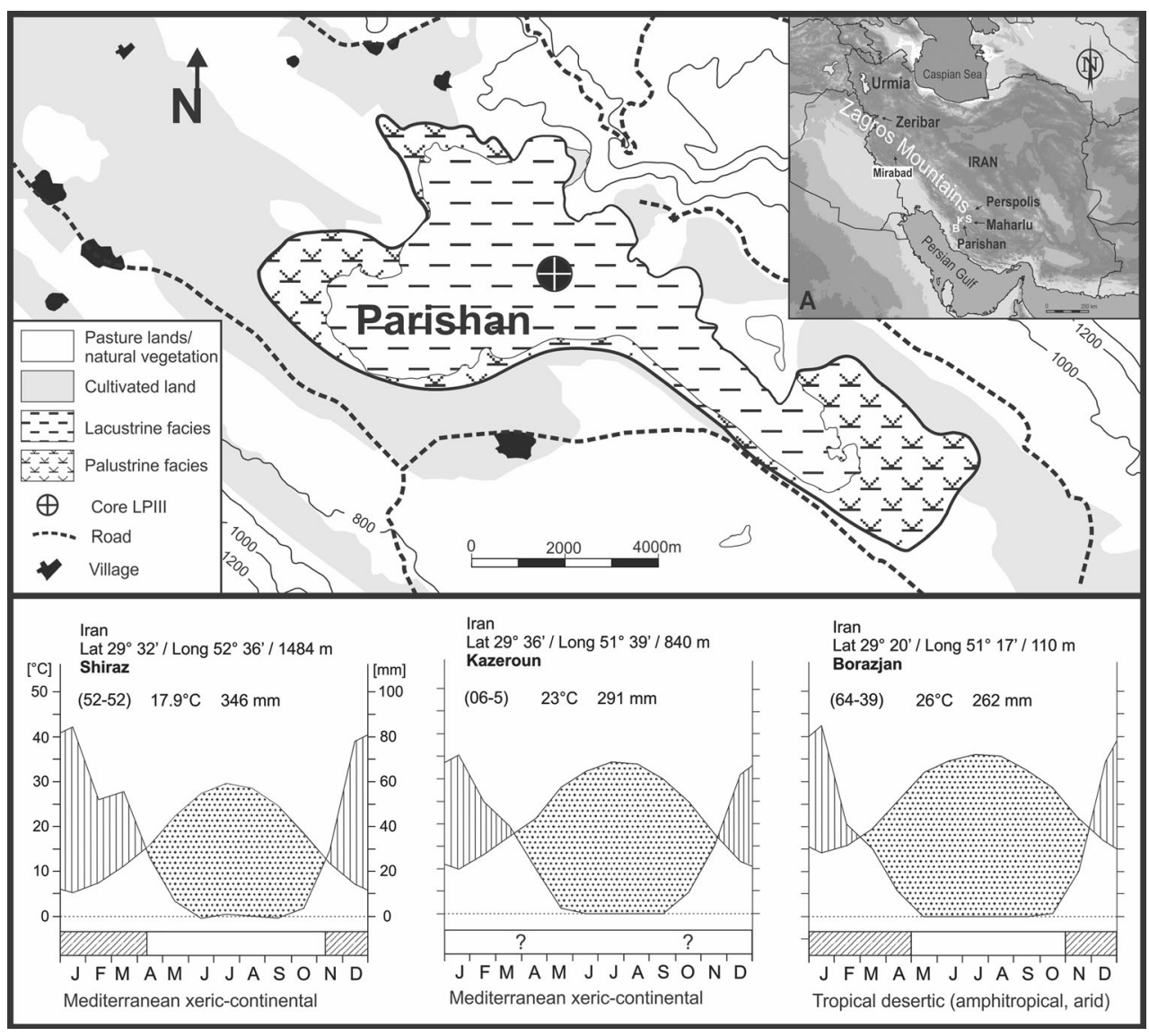

2001), it has been shown that most of the moisture over this region is brought from the Arabian and Oman Sea in the lower levels of troposphere and during the active phases of the so-called Sudan low system in winter months (Pourasghar et al. 2012).

Lake Parishan water levels are controlled by a complex hydrological balance between inputs from: (i) direct precipitation over the lake, (ii) surface run-off from the watershed, (iii) submerged and surface springs related to karstic formations and (iv) alluvial aquifers, with output due to evapo-transpiration and groundwater pumping through numerous wells (UNDP/GEF 2010).

Lake Parishan water levels have been almost continuously recorded since 1973, which gives useful information on the hydrological functioning of the lake. The lake displays seasonal water level variations so that the high stands correspond to winter months (February to June) and low stands correspond to late autumn. Lake hydrology is very sensitive to low annual precipitation, so that dry years may lead to desiccation of the lake. For instance, in 1973, 1974, 1984 and the drought interval of 2001-2005, the lake has undergone several important low stands. Also the dry interval of 1964 to 1968 led to total desiccation of the lake permitting people to cross the lake by walking (UNDP/ GEF 2010).

\section{Vegetation}

\section{Biogeographical setting}

Lake Parishan is located in the southern limit of the IranoTuranian floristic region (46\% Irano-Turanian species) with a significant number of linking species belonging to the Irano-Turanian/Saharo-Sindian (14\%) and Irano-Turanian/Mediterranean $(9.6 \%)$ regions (Dolatkhahi et al. 2009). While the presence of Ziziphus nummularia and $Z$. spina-christi (Dolatkhahi et al. 2009) shows the influence of Saharo-Sindian flora, the presence of relict populations of the typical Mediterranean tree Myrtus communis (UNDP/GEF 2010) suggests biogeographical links with Mediterranean flora.

\section{Upland vegetation}

Lake Parishan is located between three main vegetation zones: 
(i) Z. spina-christi scrub community (800-1,100 m). This vegetation type, which is described as 'mixed Forb formation with trees' in Frey and Kürschner (1989), dominates the mountains in the south and is also found on the foothills of Mount Famour, north of the lake (UNDP/GEF 2010). Tree cover is estimated at $7 \%$, of which $70 \%$ belongs to Ziziphus. Other common tree species are Pistacia khinjuk, Ficus carica and planted Populus spp. Some common herbs associated with this vegetation zone are Anthemis rodocentra, Papaver sp., Echinops sp., Avena wiestii, Ebenus stellata and Achillea milifolia (UNDP/GEF 2010).

(ii) Amygdalus scoparia scrub community ('colddeciduous open xeromorphic scrub' in Frey and Kürschner 1989) is found at 1,100-1,400 m elevation on Mount Famour. Forest cover is estimated at about $20 \%$, of which $60 \%$ is covered with Amygdalus scoparia. Other trees are Fraxinus, Ficus carica, Pistacia atlantica, Daphne mucronata, Crataegus sp. and some cultivated Olea europaea. Some common herbs found in this zone are Artemisia herba-alba, Circium congestum, Astragalus spp., Convolvulus sp., Medicago sativa and Ebenus stellata (UNDP/ GEF 2010).

(iii) Quercus brantii open woodlands are found between 1,400-2,200 $\mathrm{m}$ with about $40 \%$ tree cover. In this zone, $30 \%$ tree cover belongs to Quercus brantii and the rest is dominated by Pistacia atlantica, P. khinjuk, Amygdalus elaeagnifolia, A. lycioides, Cerasus microcarpa and Rosa canina. Some common herbs are Salvia atropatana, Tulipa clusiana, Lactuca orientalis, Allium spp., Astragalus spp. and Chaerophyllum macropodum (UNDP/GEF 2010).

\section{Aquatic vegetation}

In the Parishan wetland, the emergent vegetation is dominated by Phragmites australis, Typha sp. (most probably $T$. laxmannii) and Scirpus wardianus, all of which are found around the wetland. Najas marina is the dominant submerged plant found on the lake bottom. In the springs and canals around the wetland, the following submerged and floating plants have been reported: Ceratophyllum demersum, Myriophyllum sp., Potamogeton pectinatus, Lemna spp., Nasturtium officinale and Zannichellia palustris (Dolatkhahi et al. 2009; UNDP/GEF 2010). Aquatic plants constitute a major source of food for livestock. An estimation of the biomass of these plants shows that Typha has the highest biomass production $\left(7.3 \mathrm{~kg} / \mathrm{m}^{2}\right)$ followed by Phragmites $\left(5.9 \mathrm{~kg} / \mathrm{m}^{2}\right)$, Najas $\left(3.3 \mathrm{~kg} / \mathrm{m}^{2}\right)$ and Nasturtium $\left(2 \mathrm{~kg} / \mathrm{m}^{2}\right)$ (UNDP/GEF 2010).

Of particular interest is the presence of Myrtus communis, which forms well-established populations around some of the springs around the lake. In the waterlogged areas around the lake especially in the east, northeast and west, vast meadows have developed with Salix, Tamarix, Ricinus, Myrtus communis, Polygonum sp., Mentha sp., Alisma plantago-aquatica, Cyperus spp., Veronica sp., Cynodon sp., Juncus sp., Convolvulus sp. and Portulaca sp. In the plains located at the south of the lake, halophytic vegetation has developed (UNDP/ GEF 2010).

\section{Archaeology of the Parishan basin}

Data on the occupation history of Lake Parishan's surroundings, i.e. the present day Kazeroun basin, are scarce. The earliest traces of human occupation are the Neolithic ceramics (Mushki ceramics: early sixth millennium BC) on the Tol-i Morge site (Sumner 1977; Weeks et al. 2006). For later periods, results of recent surveys on Tol-i Djidun, located south of the modern town of Kazeroun, have recently been published (Hejabri Nobari et al. 2009). The ceramic surface collection has revealed four phases of occupation of the site from the Middle Elamite (second millennium BC) to Sassanian periods including one phase dating to the Achaemenid. The major archaeological site of the Parishan basin is the Sassanian city of Bishapur. It was founded at the beginning of the Sassanid Era, at the north end of the basin, by King Shapur I. The site was partly excavated during the early 1940 s by Ghirshman et al. (1956, 1971) who focused his work on the major monumental buildings. Later excavations occurred until the 1970s but were never published in detail. It seems clear that the foundation of this 155 ha city corresponds to a major event for the occupation history of the region. Based on the evidence of complex infrastructure including buildings, courtyards or gardens, streets, fields, qanats etc. (Amiri and Genito 2013), we can hypothesise that the development of the city was based on careful territorial management of its hinterland, particularly concerning agricultural production. Later, in the 10th-11th centuries $\mathrm{AD}$, Kazeroun emerged as the new regional centre and Bishapur was gradually abandoned (Christensen 1993). In the early 14th century AD, Kazeroun was ruined but its territory seems to have been an important linen production centre. 


\section{Materials and methods}

\section{Coring, lithology, and chronology}

A $250 \mathrm{~cm}$ long core (LPIII) was extracted from the centre of the lake $\left(29^{\circ} 30^{\prime} 50^{\prime \prime} \mathrm{N}, 51^{\circ} 48^{\prime} 08^{\prime \prime} \mathrm{E}, 823 \mathrm{~m}, 2.1 \mathrm{~m}\right.$ water depth) using a Livingstone corer. The sediment is dominated by calcareous muds (mainly clay and silty clay) with higher content of organic remains in the lower half of the section (Fig. 2). The percentages of carbonate and organic matter were measured by loss on ignition (LOI). The chronology of the core LPIII is based on three ${ }^{14} \mathrm{C}$ and one U-Series ages (Tables 1, 2). All radiocarbon samples were analysed at the Poznan Radiocarbon Laboratory, Poland. The ${ }^{14} \mathrm{C}$ ages were calibrated in CALIB 6.0.1. (Stuiver and Reimer 1993) using the IntCal09 calibration (Reimer et al. 2009). The high carbonate content of the lake sediments due to the dominance of marine calcareous formations in the Parishan catchment area strongly suggested the possibility of age aberrations due to a 'reservoir effect' ('Rf' in Fig. 2) that had to be considered in age calibrations. In order to estimate the $\mathrm{Rf}$, one U-Series date was run at The Open University, UK from the same depth as the deepest radiocarbon dated sample $(225-226 \mathrm{~cm}$; Table 1$)$. The difference between the results of ${ }^{14} \mathrm{C}$ and U-Series ages suggested an Rf value of about 330 years, which was then

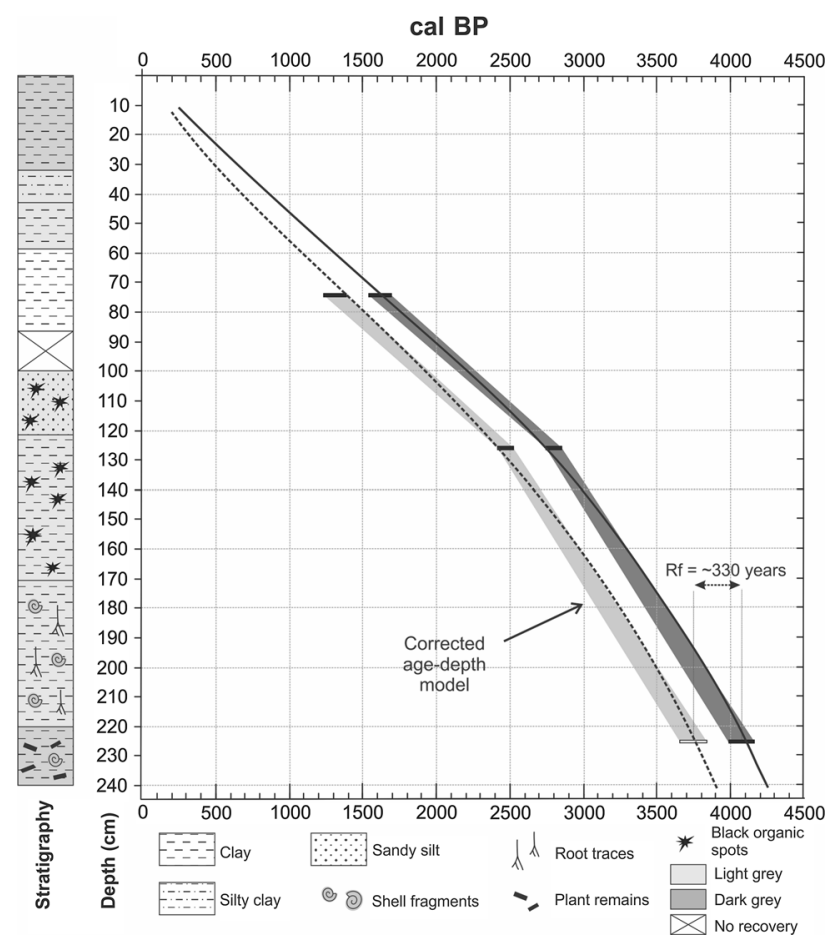

Fig. 2 Age-depth model plotted against the stratigraphical log of core LPIII. The chronology of the LPIII pollen diagram in Fig. 3 is based on left-hand side curve subtracted from the calibrated radiocarbon ages to establish the final age-depth model (Fig. 2; Jones et al. 2015). We have assumed that the $\mathrm{Rf}$ has remained relatively constant through time. In the hypersaline Lake Maharlou located $100 \mathrm{~km}$ to the east of Lake Parishan with a similar geological context, the reservoir effect was estimated to be about 800 years (Djamali et al. 2011).

\section{Pollen analysis}

In total, 26 samples were treated following the classical extraction technique described in Moore et al. (1991). In some samples, up to two extra treatments with warm $\mathrm{HCl}$ were necessary to remove the complex inorganic fractions. Pollen and spores were identified using pollen reference collections and a bibliography for Mediterranean, IranoTuranian and Saharo-Arabian regions available in the palynology laboratories of Institut Méditerranéen de Biodiversité et d'Ecologie (IMBE) and Centre Européen de l'Enseignement et de la Recherche en Géosciences de l'Environnement (CEREGE). The following references were frequently consulted: Beug (2004), Reille (1992, 1995, 1998) and Bonnefille and Riollet (1980). Pollen counts were continued until more than 300 terrestrial pollen grains were counted. Pollen percentages were calculated and then plotted as a pollen percentage diagram (Fig. 3) in TILIA and TGView, respectively (Grimm 2004, 2005). A stratigraphically-constrained zonation was also applied to pollen and non-pollen palynomorphs (NPPs) using the 'CONISS' program included in the latter software, to help the vertical subdivision of the diagram into Local Pollen Assemblage Zones (LPAZs).

A Correspondence Analysis (CA) was then applied to a matrix composed of pollen percentages of different taxa at different sampling depths using ade4 package, in $\mathrm{R}$ software version R2.15.0 (R Development Core Team 2011). This multivariate statistical technique was applied to summarize the set of data in a two-dimensional graphical form, in order to reveal the likely significant patterns, combinations and gradients in pollen taxa independent of stratigraphy (Figs. 4a, b).

\section{Modelling of potential olive yields}

In order to test the bioclimatic potential of the study area for olive cultivation, we simulated potential olive yields under scenarios of both rain-fed and irrigated agriculture, by means of the process-based vegetation model LPJmL (Lund-Potsdam-Jena managed Land, Bondeau et al. 2007; Fader et al. 2015; open discussion; Sitch et al. 2003). This model uses climate inputs (CRU 3.10; Harris et al. 2013), soil textures, and global atmospheric $\mathrm{CO}_{2}$ concentrations to model vegetation growth, phenology, and agricultural 
Table 1 Radiocarbon age report for three radiocarbon ages for three samples from the core LPIII, Lake Parishan

\begin{tabular}{lllllll}
\hline Sample number & Lab code & Depth $(\mathrm{cm})$ & ${ }^{14} \mathrm{C}$ age $($ year вP) & Calibrated age (cal year вP) & Age-ranges (cal year вP) & Material dated \\
\hline LPIII 73-74 & Poz-21263 & $73-74$ & $1,702 \pm 27$ & $1,588 \pm 48$ & $1,540-1,637(0.72)$ & Mud \\
& & & & $1,670 \pm 24$ & $1,646-1,694(0.28)$ & $2,749-2,851(1.0)$ \\
LPIII 125-126 & Poz-45410 & $125-126$ & $2,685 \pm 35$ & $2,800 \pm 51$ & Mud \\
LPIII 225-226 & Poz-21264 & $225-226$ & $3,752 \pm 30$ & $4,155 \pm 48$ & $4,067-4,163(0.68)$ & Mud \\
& & & & $4,008 \pm 20$ & $3,988-4,047(0.20)$
\end{tabular}

Calibrated ages are the means of the $2 \sigma$-ranges with highest probabilities. Age-ranges with highest probabilities (in parentheses) are also

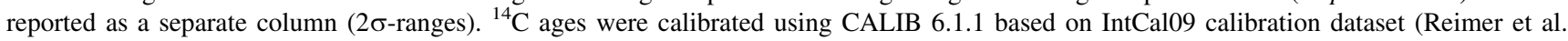
2009)

Table 2 U-series dating with $\mathrm{U}$ and Th isotope concentrations and the corrected age

\begin{tabular}{|c|c|c|c|c|c|c|c|c|}
\hline $\begin{array}{l}\text { Sample } \\
\text { code }\end{array}$ & $\begin{array}{l}\text { Material } \\
\text { dated }\end{array}$ & ${ }^{238} \mathrm{U}(\mathrm{ppm})$ & ${ }^{234} \mathrm{U}(\mathrm{ppm})$ & ${ }^{230} \mathrm{Th}(\mathrm{ppb})$ & ${ }^{232} \mathrm{Th}(\mathrm{ppb})$ & ${ }^{230} \mathrm{Th} /{ }^{234} \mathrm{U}$ & ${ }^{234} \mathrm{U} /{ }^{238} \mathrm{U}$ & $\begin{array}{l}\text { Corrected } \\
{ }^{230} \mathrm{Th} \text { age (BP) }\end{array}$ \\
\hline LPIII 225-226 & Mud & $\begin{array}{l}8.63390 \pm \\
0.06816\end{array}$ & $\begin{array}{c}0.00076 \pm \\
0.00000\end{array}$ & $\begin{array}{l}0.01427 \pm \\
0.00012\end{array}$ & $\begin{array}{l}1254.72 \pm \\
226.81\end{array}$ & $\begin{array}{l}0.033789 \pm \\
0.0004\end{array}$ & $\begin{array}{l}1.652937 \pm \\
0.0194559\end{array}$ & $3,745 \pm 90$ \\
\hline
\end{tabular}

The ${ }^{230} \mathrm{Th}$ age was corrected using ${ }^{232} \mathrm{Th} /{ }^{238} \mathrm{U}$ ratio of 3,12 . The sample number is also the sample depth $(\mathrm{cm})$

production at a spatial resolution of 30 arc minutes. For the present study, LPJmL was fed with a regular land-use input pattern allowing growth of rain-fed and irrigated olives in every grid-cell of the study region. Parameterization of the model, including optimal temperature for photosynthesis, maximal and minimal temperatures for growth and $\mathrm{CO}_{2}$ uptake, planting densities etc. were taken from literature (see Fader et al. 2015; open discussion). In order to account for irrigation infrastructure (channels, pipes, etc.) and groundwater reservoirs in addition to surface water availability, in simulating irrigated agriculture it was assumed that irrigation water was always available in the irrigated areas.

\section{Results and interpretation}

\section{Pollen data}

According to the pollen percentage diagram of Lake Parishan (Fig. 3), four main local pollen assemblage zones named after the Lake Parishan III core (LPIII) can be defined. Figure 3 shows a simplified pollen diagram of the studied core of Lake Parishan (LPIII) alongside variations in $\% \mathrm{CaCO}_{3}, \%$ organic matter, and oxygen and carbon stable isotopes (from Jones et al. 2015) to allow comparison of the pollen data with other proxies. A full dataset of pollen counts is available on the European Pollen Database (http://www.europeanpollendatabase.net/) and the Pangea database for Earth and environmental science (http://www. pangaea.de/).
LPIII-A (245-183 cm: 4,000-3,220 cal BP): The first half of this zone is characterized by relatively high values of gonyaulacales dinoflagellate cysts (most probably Gonyaulax clevei) and Riella spores with the presence of low but significant values of emergent macrophyte pollen (Sparganium/Typha). In the middle of the zone, Botryococcus blooms at $\sim 3,550$ cal BP followed by an increase in the oocytes of Neorhabdocoela. This assemblage of aquatic pollen and non-pollen palynomorphs indicates open water conditions during this zone with possibly more eutrophic conditions in its middle part. The lithology of the sediments corresponding to this zone also suggests a lacustrine environment at the start of the zone, indicated by dark grey clay with shell fragments and plant remains, followed by more palustrine conditions, indicated by appearance of potential root traces and less organic matter (Fig. 2). This lower organic content might indicate oxidation due to pedogenic activities during the dry season; seasonal desiccation of the wetland for a short interval of time cannot be excluded.

In this zone the AP/NAP ratio oscillates around $50 \%$ and tree pollen is dominated by Quercus and Pistacia, showing that regional vegetation remained almost unchanged excepting a short interval between $\sim 3,300$ to 3,200 cal BP during which tree pollen reaches its maximum value $(80 \%)$. Some low-level pastoralism is suggested by the constant, but relatively low, presence of Plantago lanceolata-type pollen and Sporormiella throughout the entire zone.

LPIII-B (183-130 cm: 3,220-2,510 cal вP): Sparganium/Typha and Cyperaceae increase during this pollen 


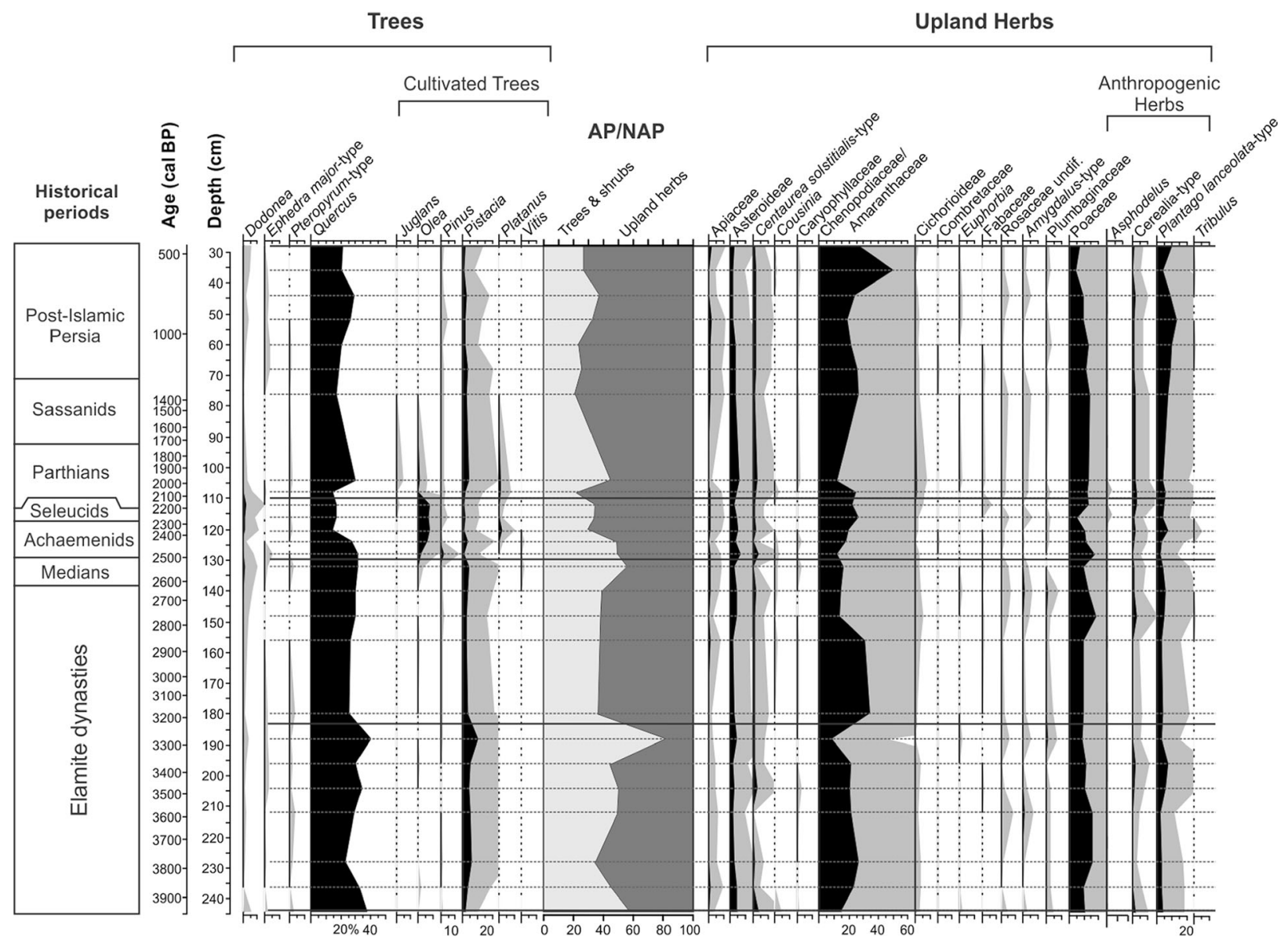

Fig. 3 Simplified pollen percentage diagram of core LPIII. CA Axis 1 scores are plotted to the right of the diagram to show the general trend in anthropogenic pollen indicators. Main dynasties which have ruled over the study region are also shown to the left of the diagram

zone, indicating the development of more shallow wetland environments, favourable for the development of emergent macrophytic vegetation and marsh environments at, or near, the coring site. AP/NAP ratios decrease to $\sim 40 \%$ and remain constant throughout this pollen zone showing no significant changes in regional vegetation. Higher values of Chenopodiaceae (Salicornia-type) are most probably related to halophilous chenopods growing in the littoral marshes and saline soils around the lake. A relatively low lake level is supported by a decrease in Botryoccocus, dinoflagellate cysts, and oocytes of Neorhabdocoela.

LPIII-C (130-110: 2,430-2,110 cal вP): This pollen zone displays the most dynamic vegetation change during its relatively short duration.

\section{Upland pollen}

The most spectacular feature of the LPIII pollen diagram is the appearance and then maximum values of pollen of cultivated trees including Olea, Platanus, Vitis and later Juglans in this zone. The CA scatter plots of samples and pollen taxa in Fig. 4a, b clearly show that the cultivated tree pollen has the highest positive values on CA Axis 1 and these correspond to the samples coming from zone LPIII-C. Olea is, by far, the most dominant cultivated tree pollen in the zone reaching the maximum values of $8.2 \%$ at $120 \mathrm{~cm}$ depth corresponding to 2,360 cal BP (Fig. 3). The appearance, for the first time, of significant amounts of Pinus pollen at the beginning of the zone is also suggestive of the planting of Pinus in the southern Zagros, given the total absence of genus Pinus in the flora of Iran (Riedl 1968). Contemporary with the increase in cultivated trees, the pollen percentages of the Saharo-Sindian shrub Dodonaea viscosa also increase and form a continuous curve attaining their highest values in the whole record. The presence of Dodonaea pollen is an interesting feature of the LPIII-C pollen zone and is treated in more detail in the Discussion.

Aquatic pollen and NPPs. Zone LPIII-C starts with an explosion of Riella spore values and oocytes of Neorhabdocoela, followed by a significant increase of dinoflagellate cysts and Sparganium/Typha pollen. Botryococcus is also present at slightly higher values than in LPIII-B. The peak of Riella at the beginning of this zone most probably suggests somewhat unstable hydrological conditions 

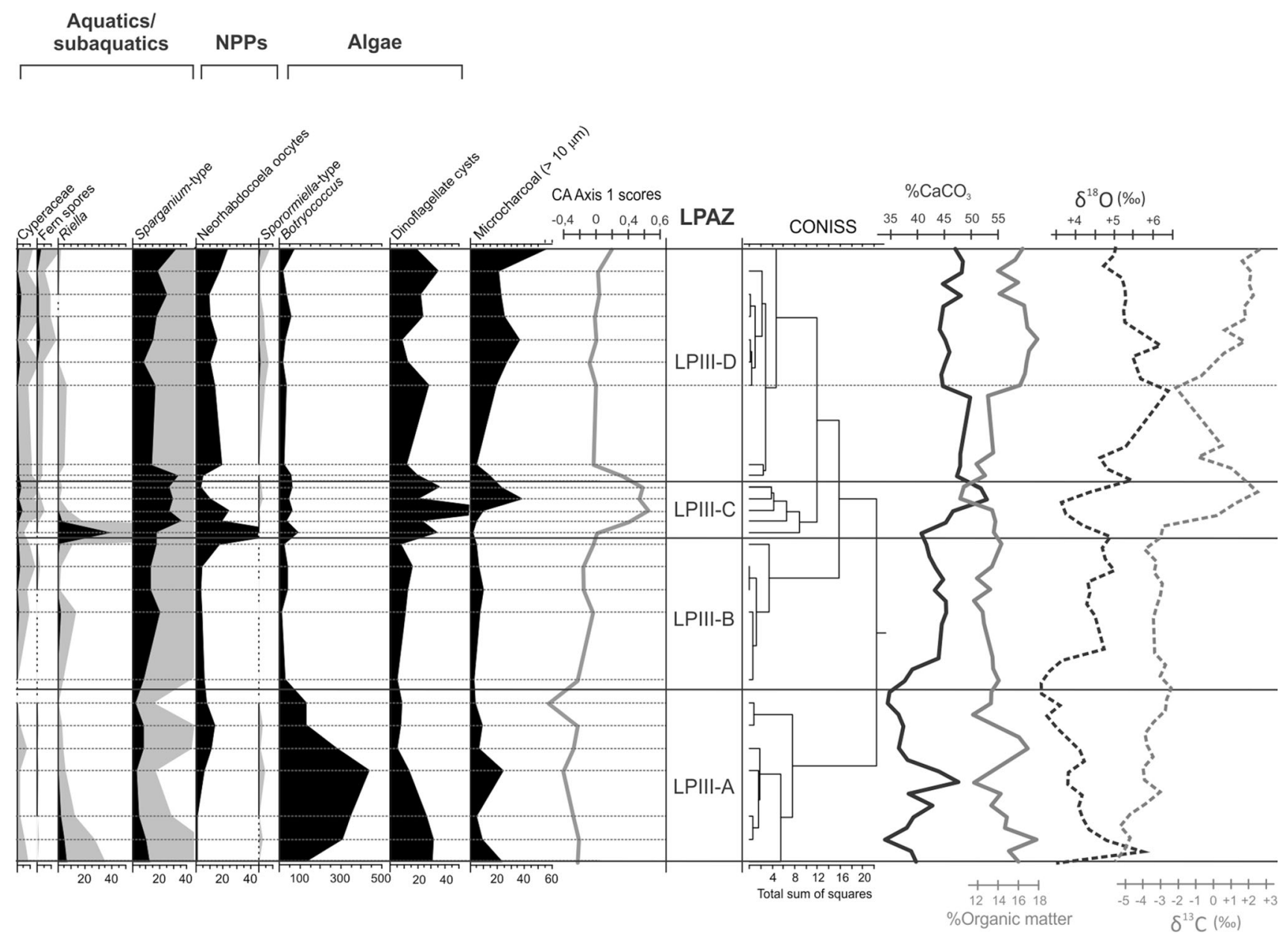

Fig. 3 continued

characterized by a marked long dry season interrupted by seasonal flooding. Water chemistry during the flooding of littoral zones might have been brackish and slightly alkaline ( $\mathrm{pH} 7-8$ ), favouring the development of a subaquatic carpet of the liverwort Riella in flat marginal areas around the lake (Djamali et al. 2008). Beginning 2,470-2,500 cal вP, the lake level rose and became more stable, causing the expansion of dinoflagellates and a denser macrophytic vegetation belt around the lake margins. A biogenic sandy silt deposit in this zone denotes a lacustrine environment with high productivity (Fig. 2). The highest amount of carbonates and the lowest amount of organic matter are found in this pollen zone, confirming that oligotrophic conditions dominated during this pollen zone. If the peak in reeds (Sparganium/Typha) is interpreted as the presence of a dense macrophytic stand at the site of coring, one would expect a peak in organic matter corresponding to the highest pollen values of these plants. The absence of such a peak would rather indicate that the emergent macrophytic vegetation belt developed in the littoral zones far from the coring site.
The presence of a significant peak in microcharcoals and a slight increase in Sporormiella spores and Plantago lanceolata-type pollen show an increase in human activities in the catchment area of Lake Parishan towards the end of zone LPIII-C. Such intensification of human activities may also have affected the lake hydrobiochemistry, e.g. favouring algal blooms through higher nutrient inputs. Comparing pollen data with other proxy data gives some clues as to the extent of such relationships. $\delta^{18} \mathrm{O}$ shows more negative values in this pollen zone (Fig. 3) suggesting higher lake levels, and diatom and ostracod fauna also change in this part of the record (Jones et al. 2015), suggesting a change in the hydrochemistry of Lake Parishan, most probably linked to the intensification of human activities (Jones et al. 2015).

In summary, changes in pollen and other proxy data during the LPIII-C pollen zone suggest a period of significant agriculture in the catchment, lasting for more than 3 centuries, during the second half of the first millennium $\mathrm{BC}$.

LPIII-D (110-27 cm: 2,110-500 cal BP): Pollen percentages of the main arboreal taxa, dominated by Quercus 

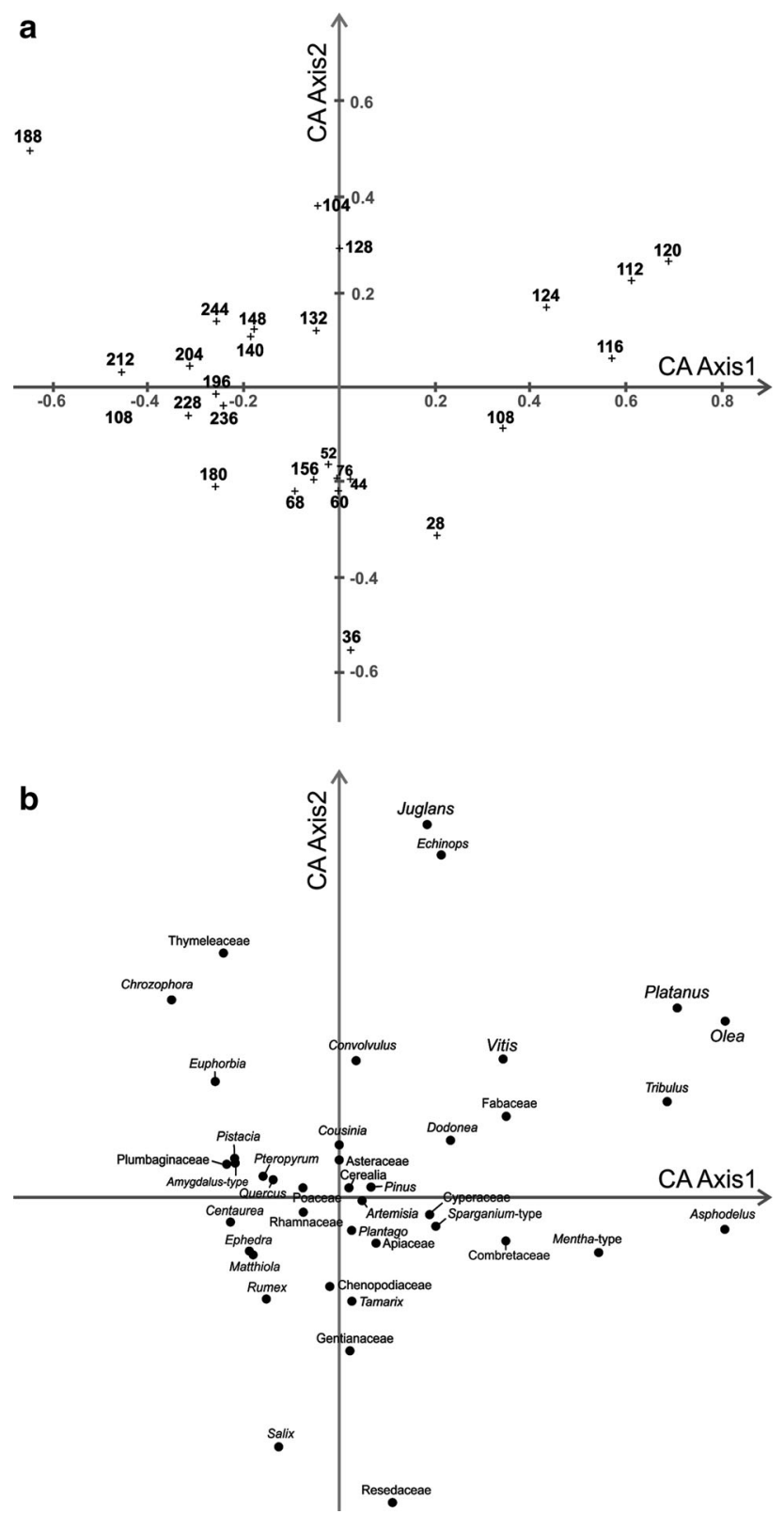

Fig. 4 Scatter plot of the CA Axes 1 and 2 scores for sample depths (a) and pollen taxa (b). Note the concentration of cultivated trees to the right corresponding to the samples coming from zone LPIII-C, showing that this axis indicates a gradient in agricultural activities. Numbers besides plus (+) signs denote the depth of the treated samples in $\mathrm{cm}$ below the lake bottom

and Pistacia, and also of many upland herbs, remain unchanged during this pollen zone showing that the regional vegetation kept its main physiognomy. Although pollen of cultivated trees declines and then disappears during this pollen zone, Plantago lanceolata-type pollen and the fungal spores of Sporormiella-type show increasing values during this pollen zone, suggesting the intensification of pastoral activities. A 5-10\% decrease in natural tree pollen compared to LPIII-B and a high concentration of microcharcoals

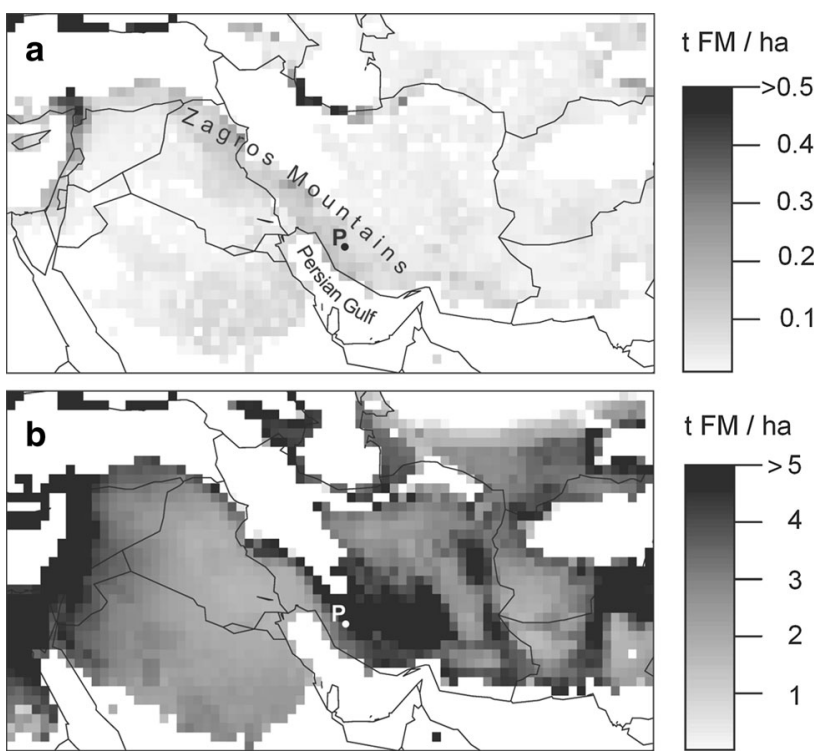

Fig. 5 Maps showing the potential rain-fed (a) and irrigated (b) yields of olive in the Middle East based on LPJmL model outputs. Potential olive yields are reported in tons of fresh matter per hectare under rain-fed and irrigated conditions as average for the period of time 2000-2009. It is noted that the southern Zagros can potentially produce a high yield of olive under irrigation

may also be due to pressure of pastoralism on the Zagros oak woodlands and pistachio-almond scrubs.

Pollen of the aquatic plants Sparganium/Typha, oocytes of Neorhabdocoela, Botryococcus, and dinoflagellate cysts show lower abundances compared to the short-lived LPIII-C pollen zone but they are high enough to suggest an open lake environment in the central basin with fresh- to brackish marshes bearing dense emergent reeds (Sparganium/Typha and most probably Phragmites) at the lake margins. A peak in dinoflagellate cysts centred on $400 \mathrm{cal}$ BP shows a possible substantial lake high stand. The Correspondence Analysis (CA) (Fig. 4) performed on pollen percentages revealed that pollen spectra corresponding to this zone form a distinctive assemblage on the positive side of CA Axis1, which explains $29.6 \%$ of the variability. This axis seems thus to represent a gradient towards anthropogenic activities and especially agricultural-related practices. The fact that the pollen of Tribulus and Asphodelus (despite low pollen values) are grouped together with major cultivated taxa suggests their close relation with human activities. They most likely represent vegetative response to increasing soil erosion and overgrazing in the area (e.g. Djamali et al. 2009a, 2012), as both are species that colonize disturbed areas.

\section{Maps for potential olive production}

Figure 5 depicts the potential olive yields in tons of fresh matter per hectare under rain-fed and irrigated conditions in 
SW Iran, as average for the period of time 2000-2009. Potential rain-fed and irrigated yields of olive (Fig. 5a, b, respectively) look well correlated with temperature patterns and suggest higher yields in the southern foothills of the Zagros Mountains including the Lake Parishan area (shown by 'P' in Fig. 5a, b). In both cases excessively high temperatures (close to the coast of the Persian Gulf) or low temperatures (in the higher mountains) constrain growth or even prevent the establishment of saplings. However, both maps suggest that olive trees can be potentially cultivated in the southern Zagros with significant yields, with irrigated yields being substantially higher than yields under rain-fed conditions.

\section{Discussion}

\section{Olive cultivation and spatial organization of arboricultural practices in Persis (ancient Fars) during the imperial period}

In the Persepolis Fortification Tablets (PFTs) written by the Persepolis administration in the Achaemenid Elamite language, the word "GIŠ za-a-da-um" has generally been interpreted as olive tree (GIŠ is the sumerogram meaning tree) (Hinz and Koch 1987; Tavernier 2007). This word has been mentioned in only one text among those so far studied (Hallock 1978, PFa 33) and therefore cannot be interpreted as solid proof of olive cultivation. However, this text is the only inventory of seedlings currently identified among the PFTs suggesting that seedlings of olive trees were planted in the area controlled by the Persepolis administration in Achaemenid times. According to some Greco-Roman written sources, olive cultivation was practiced neither in Persis nor in the neighbouring regions in Achaemenid and later times. In Indica, Arrian notes that in the most fertile part of Persis every kind of fruit grows except for the olive (Arr. Ind. 40.3) (Arrian 1983). Strabo in Book 11 of his Geography states that Media, to the south of the Caspian Gates, is fertile and produces every kind of fruit except for olive, which, if it grows anywhere, does not yield oil and is dry (Strab. 11.13.7) (Strabo 1928). In Book 15, he writes that Carmania (modern Kerman, SE Iran) produces all manner of fruits and is full of large trees except the olive (Strab. 15.2.14) (Strabo 1930). However, for later periods, Ghirshman et al. (1971, p. 22), the first excavator of the Sassanian city of Bishapur, states "[...] l'olivier, disparu aujourd'hui formait sous les Sassanides une arboriculture célèbre par son étendue." Ghirshman does not give a reference in his texts and the primary Sassanian historical administrative sources are known to be poor in detail. He may be referring to the geographies of the 10th century $\mathrm{BC}$ in which the cultivation of olive as well as other trees is attested in the Bishapour surroundings (Le Strange 1905, p. 262).

Given the above, our discovery of clear evidence pointing to the practice of olive cultivation in Persis raises interesting questions, including how the tree was introduced into the heart of the Persian Achaemenid Empire to start with. Our current age-depth model is in favour of an introduction during the Achaemenid rather than the Seleucid period. However, the possibility that olive cultivation was also practiced during the Seleucid period cannot be excluded. As the olive pollen appears at about the beginning of the Achaemenid period and the tree was then apparently planted in substantial numbers, it can be hypothesized that the Persians encountered this tree especially after their conquests in the Eastern Mediterranean and then introduced it into their homeland. This hypothesis also seems to be confirmed by the fact that the term used to indicate the olive in the Achaemenid Elamite and Persian languages (zadaum and *zaita-; MP zayt) were West Semitic loanwords. Greek authors' perception that no olives grew in Persia is more likely based more on their observation that Persians were unfamiliar with the tree than on any direct accounting of agricultural practices throughout the Persian Empire. The possible introduction of olive cultivation in Egypt under the Persian Empire during the latter part of first millennium BC (Newton et al. 2006) also suggests olive cultivation was an important part of Persian agriculture.

\section{Regional patterns}

In a 4,700-year pollen record from Lake Maharlou, $100 \mathrm{~km}$ to the east of Parishan, a large-scale arboricultural phase centred on 2,500 cal BP during the Achaemenid Empire has been shown by significant quantities of Juglans, Platanus and to a lesser degree Olea pollen (Djamali et al. 2009a). However, a cultivated origin for the olive pollen in the Maharlou Basin remains uncertain, due to the possibility that it might come from wild stands and/or distant sources probably located in the Persian Gulf area (Djamali et al. 2009a, 2011). Today, Olea is represented by two species (O. aucheri and $O$. ferruginea) in the Saharo-Sindian region of Iran (Murray 1968). However, these are generally found as isolated trees and rarely form well-established populations. New findings from Lake Parishan strongly suggest that the plains and mountain foothills around the lake were extensively cultivated with the olive tree, not only by the Achaemenids but also later during the Seleucid period. The absence of pollen spectra from 114 to $76 \mathrm{~cm}$ depth makes it difficult to retrace tree cultivation practices during the Sassanian Empire. At Maharlou, the Sassanian period is characterized by a second important arboricultural phase (Djamali et al. 2011). This latter observation does not fit with the settlement evolution of the Parishan basin 
because the foundation of the city of Bishapur seems to show that the Sassanian era was a period of major development for the region. However, Bishapur was founded $30 \mathrm{~km}$ to the northwest of Lake Parishan in the north part of the basin. This location might suggest that during Sassanid times the northern part of the plain was more cultivated than the surroundings of the lake to the south. Nevertheless the distance does not seem great enough to explain the absence of traces of arboriculture in the proxy data from Lake Parishan in this period. We could suggest a preliminary explanation by taking into account the topography of the plain. Narrowing of the valley between Bishapur and the lake might have meant that topographic relief affected the pollen rain coming from the north. This hypothesis would suggest that the data from Parishan are linked specifically to the vegetation variations of the south part of the basin.

Olea is considered as a relatively under-represented tree in modern pollen rain. Very high values of Olea pollen, such as those reported from the Minoan period on Crete, up to $50 \%$ (Renard 2014), are exceptional cases indicating the massive olive cultivation in close proximity to palaeoecological study sites. Modern pollen samples analysed within the modern distribution area of Olea in Anatolia reveal pollen percentages between 1.6 and $8.4 \%$ (Bottema and Woldring 1990), whereas a study in southwestern Turkey demonstrates that Olea percentages vary between 3 and $40 \%$ in surface samples from within Olea plantations in the Eu-Mediterranean zone (Van Zeist and Bottema 1991). A recent study on the pollen representation of Olea europaea in surface samples of different vegetation types located close to olive orchards in SW Turkey indicates that the pollen percentages of this tree can vary between 0.0 and $1.7 \%$ (Vermoere et al. 2003). In another pollen rain study of olive orchards in Basilicata, South Italy (Florenzano 2013), it has been shown that pollen percentages inside the olive stands vary between 7.6 and $56.4 \%$ but fall down to $2.1-7.6 \%$ at $500 \mathrm{~m}$ from the stand. Modern samples from steppe regions in Syria (Van Zeist and Bottema 1991) show a presence of Olea pollen in surface samples in which it is obviously due to long-distance transport, evidence of how well olive pollen disperses. The broad variation in the percentages at which Olea pollen is represented even within olive stands is likely due to this efficient dispersal, making its deposition highly contingent on local conditions. In fossil pollen zones of three records in Anatolia, characterized by pronounced olive cultivation, mean olive pollen percentages vary between 3.6 and $13.9 \%$ (Bottema and Woldring 1990). During the 'Beyşehir Occupation phase' ( $\sim 3,600$ to $\sim 3,400$ cal $\mathrm{BP})$, described in Asia Minor by Bottema and Woldring (1990), the Olea pollen percentages rarely exceed $10 \%$ of the pollen sum. Therefore, the pollen percentage values of Olea recorded in the LPIII-C zone of Lake Parishan, varying between 0.7 and $8.2 \%$, falls within the range suggesting a landscape composed of small-scale olive stands distributed over a large surface area around the lake.

The new findings from Lake Parishan, alongside the Lake Maharlou record, also allow us to begin to discuss the spatial organization of arboricultural practices in historic Persis. Among the three major planted trees-i.e. Platanus, Olea and Juglans-only the Platanus pollen is found with similar abundance in both the Maharlou and Parishan pollen records, reflecting the widespread cultivation of plane trees in streets and gardens for their shade at a time of the development of urban centres in the Achaemenid Empire heartland (Djamali et al. 2011). To date, there is no evidence of the presence of urban centres in the Lake Parishan area until the Sassanian era and part of the plane pollen may have come from adjacent basins such as the Persepolis Basin, as Platanus pollen is widely wind-dispersed. Juglans was the most important cultivated tree around Lake Maharlou, while Olea was the major arboricultural element encountered around Lake Parishan $100 \mathrm{~km}$ to the west. Different bioclimatic conditions mostly due to different elevations ( $823 \mathrm{~m}$ for Lake Parishan and 1,450 $\mathrm{m}$ for Lake Maharlou) in these two adjacent basins could at least partly explain these distinct spatial patterns. As is shown in the three climate diagrams of Fig. 1, in the period for which instrumental records are available both the average minima of the coldest month and the absolute minimum temperatures in Borazjan (60 km to the southwest of Parishan) are considerably higher than in Shiraz (85 km to the east of Parishan). The lowest temperature ever recorded for Borazjan has been $-1.5^{\circ} \mathrm{C}$ while it has dropped as low as $-14.0{ }^{\circ} \mathrm{C}$ in Shiraz. This value can decrease to $-8{ }^{\circ} \mathrm{C}$ for Kazeroun at $15 \mathrm{~km}$ to the west of Lake Parishan (UNDP/GEF 2010). In all three of these stations, the average of minima of the coldest month is over $0{ }^{\circ} \mathrm{C}$. While Juglans can more easily tolerate highly continental conditions with higher summer and lower winter temperatures, Olea is very sensitive to prolonged freezing temperatures. In this context, we can suggest that higher elevation plains and mountain areas around Lake Maharlou seem more suitable for walnut, while the lower plains around Lake Parishan appear better suited for olive cultivation.

However, during fieldwork in the Persepolis and Lake Maharlou basins in 2012 and 2013, we encountered vast areas covered by olive plantations fed by drip irrigation (Fig. 6). These plantations not only show the high agroclimatic potential of the region for oleoculture, also confirmed by the potential olive yield maps presented in Fig. 5, but also suggest that olive cultivation is again becoming an important component of the local economy in the southern Zagros. 

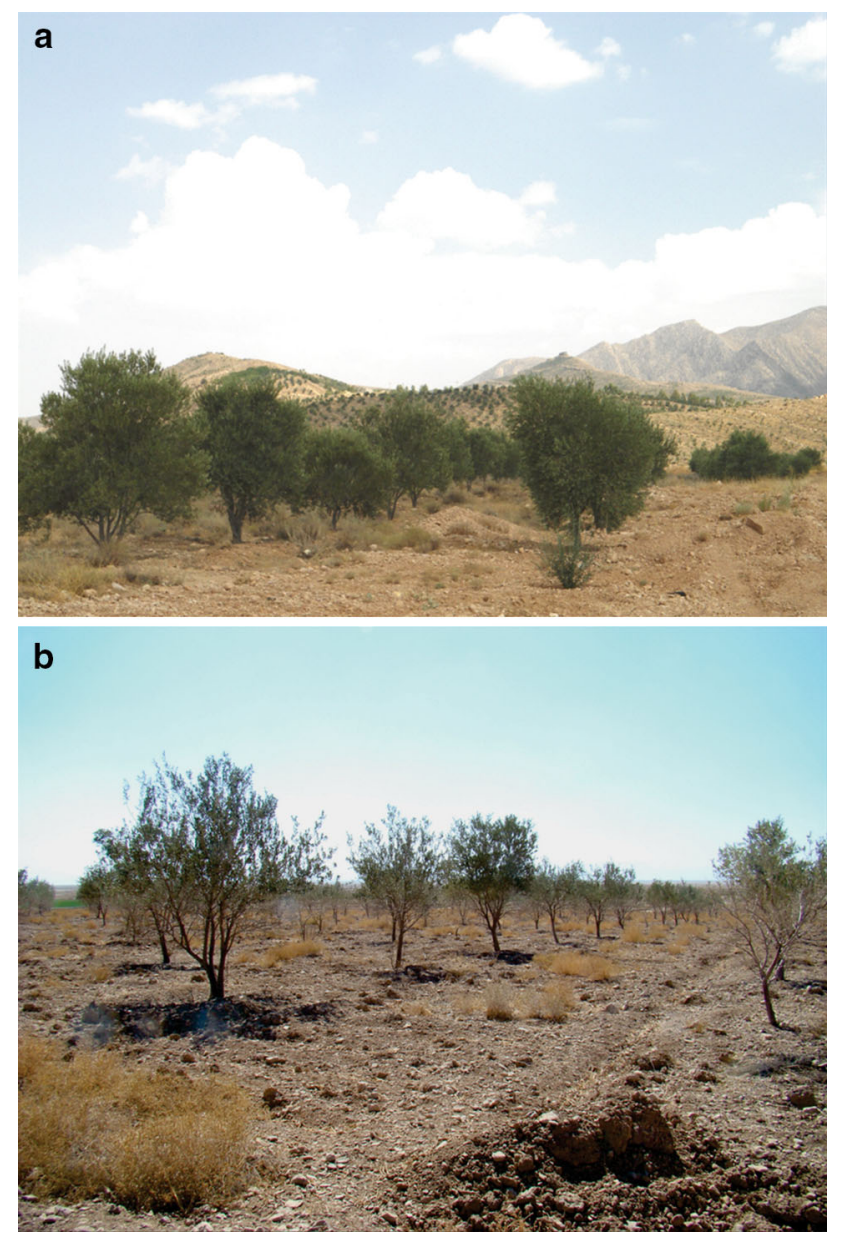

Fig. 6 Pictures of modern olive cultivation to the south of Lake Maharlou (a) and in the eastern part of the Persepolis Basin (b)

Finally, the presence of the typical Mediterranean tree Myrtus communis associated with springs (UNDP/GEF 2010) in the Lake Parishan basin is evidence of suitable bioclimatic conditions for growing other cold-sensitive Mediterranean plants such as Olea europaea. The presence of $M$. communis in association with many other Mediterranean plants in the southern Zagros and north Persian Gulf areas suggests that Mediterranean flora could have once been a more important component of the vegetation in this part of the Middle East. Our new palaeoecological insights enhance our understanding of the close biogeographical links existing between Mediterranean, Irano-Turanian and Asiatic floras, also illustrated by extensive phylogeographical studies, undertaken notably on $M$. communis (Migliore et al. 2012), Haplophyllum sp. (Manafzadeh et al. 2013) and Arundo sp. (Hardion et al. 2014).

The presence of Dodonaea pollen in the LPIII pollen record is of particular biogeographical interest. Dodonaea viscosa is an evergreen shrub, up to $2 \mathrm{~m}$ high, of the Sapindaceae family. It is native to Australia but has a pantropical distribution (Pickering and Patzelt 2008). In southwestern Asia, it is commonly found in the Arabian Peninsula and particularly in Oman (Pickering and Patzelt 2008; Winbow 2008). In Oman, it is found wild in a broad altitudinal range $(150-2,500 \mathrm{~m})$ throughout the country including in the Hajar Mountains, Dhofar Mountains, and even on lower and drier slopes and in Commiphora-Acacia shrublands (Ghazanfar 2007). It has even been reported in association with wild olive trees to form a MonothecaOlea-Dodonaea zone in the northern mountains of Oman (Ghazanfar and Fishers 1998). Such a plant community has not, however, been reported from the Iranian Zagros. In Iran, Dodonaea is found in the Saharo-Sindian region of southern Iran, very close to the Persian Gulf and the Oman Sea (Rechinger 1966; Sabeti 1976). According to Flora Iranica (Rechinger 1966), the nearest populations to Lake Parishan area are located about $300 \mathrm{~km}$ to the southeast. It is thus absent from the flora of the study area today, and it is very unlikely that the tree migrated hundreds of kilometres to the north to form well-established populations in Lake Parishan area in the past. Because of its bright green leaves, narrow vertical grooves on its stems, beautiful red tinge of the seed pods, and its being easy to prune, Dodonaea is frequently cultivated as ornamental tree and as landscaping hedge in Oman (Winbow 2008). In the cities of SW Iran and particularly in Abadan, it is commonly planted as an ornamental and hedge plant (Sabeti 1976). The increase of Dodonaea pollen during the period of the Persian Achaemenids, Seleucids, and the transition from Seleucid to Parthians can thus be interpreted as anthropogenic, resulting from the planting of decorative gardens and/or hedges to demarcate agrarian lands (e.g. Winbow 2008). In the Lake Parishan area, the occurrence of Dodonaea pollen can be interpreted in two different ways. First, its association with Olea pollen could indicate a plant community similar to that found today in the mountains of Oman, developed due to particular climatic conditions. Secondly, its association with Olea and other cultivated trees (Platanus and Juglans) could be related to agricultural and arboricultural practices. As mentioned above, the absence of wild Olea-Dodonaea in the southern Zagros today and the contemporaneous appearance of all cultivated trees both strongly suggest the anthropogenic nature of the increase in Dodonaea pollen.

\section{Hydrological change in Imperial Persia}

Variations in relative frequencies of certain aquatic plants and NPPs can be used as proxies for lake level changes and interpreted alongside other proxies of lake hydrological change, e.g. oxygen isotopes (Fig. 3). In the Lake Parishan record, some high- and low-stands can be inferred by comparison of the curves of aquatic pollen (Cyperaceae and particularly Sparganium-type), Riella spores, oocytes of 
Gyratrix hermaphrodites, green algae Botryococcus and dinoflagellate cysts. Neorhabdocoela is an order of small flatworms belonging to the microturbellarians, which inhabit aquatic environments from freshwater to marine and are mainly restricted to the phytal zone, feeding on diatoms and Rotatoria (Haas 1996). Gyratrix hermaphroditus is a lacustrine, eurythermic $\left(1-25^{\circ} \mathrm{C}\right)$ and euryhaline species with a $\mathrm{pH}$ tolerance of 4.7-9.4 (Haas 1996). High abundance of oocytes of Neorhabdocoela occur together with Botryococcus and freshwater dinoflagellate cysts, suggesting the highest water level during zones LPIII-C and the lowest during zone LPIII-B. A lake high-stand during zone LPIII-C is also reflected in the sediment composition, with increased values of biogenic sands. Similar to this record, maxima of oocytes of Neorhabdocoela ( $G$. hermaphroditus) in a record from the Andes were associated with high water level, coinciding with peaks of Pediastrum and Botryococcus (Rull et al. 2008). However, the opposite relation of $G$. hermaphroditus to dinoflagellate cysts, and to a lesser extent to Botryococcus, in LPIII is remarkable. Due to competition for light, green algae and autotrophic gonyaulacales dinoflagellates prefer lacustrine conditions to palustrine, where higher plants dominate, and therefore, are useful indicators of open water. In comparison, microturbellarians profit from spreading of macrophytes, which provide additional ecological space in terms of protection and food presence. This would explain the coincidence of maxima of oocytes of Neorhabdocoela and Riella spores at the beginning of zone LPIII-C. Riella is the only bryophyte species growing in salty environments (e.g. Frahm 2001; Miehe et al. 2006). A Riella explosion at the beginning of the zone could indicate the start of seasonal inundation of flat saline marshes around the lake. These conditions could be fruitful for microturbillarians, which might expand together with Riella. The later explosion and dominance of Sparganium-type pollen (most probably of Typha laxmannii), Botryococcus and freshwater dinoflagellate cysts indicates a potential high-stand lasting for about 5 centuries. This remarkable hydrological event in LPIII took place during the Achaemenid, Seleucid and early Parthian Empires, suggesting that this time period was contemporaneous with higher lake levels in Lake Parishan.

Comparisons of the pollen record with other proxies in the LPIII core suggest that the agricultural practices themselves are the most likely control on lake hydrological change (Jones et al. 2015). The beginning of zone LPIII-C is marked by the best preserved diatoms in the record, suggesting that the water was freshest in this part of the record and/or that nutrients were easily available, and this zone is also marked by a negative excursion in $\delta^{18} \mathrm{O}$, again suggesting a freshening of the water in the system that matches the higher lake levels suggested by the aquatic pollen and NPP data. The ostracod faunal assemblage also changes at this point in the record, and for most of this zone, but suggests reduced surface and groundwater input into the lake, particularly in the latter part of the zone when oak pollen is substantially reduced (interestingly this deforestation seems to postdate the beginning of olive agriculture). These other proxies therefore suggest increased input of water into the lake at the beginning of pollen zone $\mathrm{C}$, but lowering lake levels later in the zone. It can be argued that the initial catchment disturbance, especially due to deforestation, increased the water inflow into the lake through increased runoff and thus explaining the higher lake levels at the beginning of zone LPIII-C. In general, throughout the core, periods with evidence of increased human activity (e.g., deforestation, increased burning, olive cultivation, higher Sporormiella counts indicating pastoral activity; e.g. see LPIII-D zone in Fig. 3) are marked by more positive $\delta^{18} \mathrm{O}$ isotope values and an ostracod faunal assemblage suggesting reduced water inflow from the catchment (Jones et al. 2015). It therefore appears that agricultural activity in the Parishan catchment has had a significant impact on the lake hydrology for some time.

\section{Conclusions}

This study is a good example of how palaeoecological investigations can be complementary to historical and archaeological data. The core from Lake Parishan produced data that archaeological materials have not, regarding a scale of human activity with which archaeological investigation can rarely engage in the absence of well-preserved archaeological landscapes. In this case, although neither archaeological evidence nor historical documents available at present provide any clear reference to olive cultivation in southern Persis in antiquity, pollen evidence strongly suggests an important phase of oleoculture during the Achaemenid and Seleucid periods around Lake Parishan. The spatial resolution of pollen records in the southern Zagros is still extremely low, making it difficult to gain a detailed image of spatial patterns of agricultural and arboricultural practices. However, our comparison here of two pollen records in relatively close proximity highlights the potential insights that can be gained from such work. Given the scarcity of palaeoecological archives, the comparison of pollen data from archaeological records (on-site) as well as from lake/peat bog records (off-site) would be useful to increase the resolution, covering the gaps in pollen data in space and time (e.g. Mercuri et al. 2013). Even the relatively coarse spatiotemporal resolution of this study has been able to show that historical and archaeological records of the Persian imperial periods can be revised and enriched by incorporating palaeoecological evidence. 
Acknowledgments This study was supported by the Mamasani Archaeological Project; a Australian-British-Iranian Archaeological cooperation directed by Dan Potts, Cameron Petrie, LW and the Iranian Centre for Archaeological Research. It was also partly supported by the European ERC project (Grant No. 295375) entitled: "PERSIA: Persia and its neighbours: the Archaeology of Late Antique Imperial Power in Iran". The contributions of M. Fader and D. Contreras were supported by the Labex OT-Med (no ANR-11LABX-0061) and the A*MIDEX project (no ANR-11-IDEX-000102). The first author wishes to thank Guillaume Buchet for his availability, patience and invaluable help during the pollen identifications done in CEREGE palynology laboratory. MJ and LW thank their collaborators in retrieving the core material, in particular Hajar Askari, Alireza Askari, Alireza Sardori, Arash Lashkari and Kourosh Alamdari.

\section{References}

Amiri M, Genito B (2013) Bīšāpūr and its territory (Fars, Iran). Newsletter di Archeologia CISA 4:1-45

Arrian L (1983) Anabasis of Alexander, vol 2, books 5-7, Indica. Loeb Classical Library 269 (P.A. Brunt, Trans.). Harvard University Press, London

Besnard G, Khadari B, Navascués M, Fernández-Mazuecos M, El Bakkali A, Arrigo N, Baali-Cherif D, Brunini-Bronzini de Caraffa V, Santoni S, Vargas P, Savolainen V (2013) The complex history of the olive tree: from late quaternary diversification of Mediterranean lineages to primary domestication in the northern Levant. Proc R Soc B 280:20122833

Beug H-J (2004) Leitfaden der Pollenbestimmung für Mitteleuropa und angrenzende Gebiete. Pfeil, München

Bondeau A, Smith P, Zaehle S, Schaphoff S, Lucht W, Cramer W, Gerten D, Lotze-Campen H, Müller C, Reichstein M, Smith B (2007) Modelling the role of agriculture for the 20th century global terrestrial carbon balance. Glob Change Biol 13:1-28

Bonnefille R, Riollet G (1980) Pollen des savanes d'Afrique Orientale. CNRS Editions, Paris

Bottema S, Woldring H (1990) Anthropogenic indicators in the pollen diagrams of the Eastern Mediterranean. In: Bottema S, EntjesNieborg G, van Zeist W (eds) Man's role in the shaping of the Eastern Mediterranean landscape. Balkema, Rotterdam, pp 231-264

Christensen P (1993) The decline of Iranshahr-irrigation and environments in the History of the Middle East $500 \mathrm{BC}$ to $\mathrm{AD}$ 1500, Museum Tusculanum Press, University of Copenhagen, Copenhagen

Djamali M, Kürschner H, Akhani H, De Beaulieu J-L, Amini A, Andrieu-Ponel V, Ponel P, Stevens L (2008) Palaeoecological significance of the spores of the liverwort Riella (Riellaceae) in a late Pleistocene long pollen record from the hypersaline Lake Urmia, NW Iran. Rev Palaeobot Palynol 152:66-73

Djamali M, De Beaulieu J-L, Miller NF, Andrieu-Ponel V, Lak R, Sadeddin M, Akhani H, Fazeli H (2009a) Vegetation history of the SE section of Zagros Mountains during the last five millennia; a pollen record from the Maharlou Lake, Fars Province, Iran. Veget Hist Archaeobot 18:123-136

Djamali M, De Beaulieu JL, Miller N, Andrieu-Ponel V, Berberian M, Gandouin E, Lahijani H, Ponel P, Salimian M, Guiter F (2009b) A late Holocene pollen record from Lake Almalou in NW Iran: evidence for changing land-use in relation to some historical events during the last 3700 years. J Archaeol Sci $36: 1,346-1,375$

Djamali M, Miller NF, Ramezani E, Akhani H, Andrieu-Ponel V, De Beaulieu J-L, Berberian M, Guibal F, Lahijani H, Lak R, Ponel P
(2011) Notes on the arboricultural and agricultural practices in ancient Iran based on new pollen evidence. Paléorient 36:175-188

Djamali M, Gambin B, Marriner N, Andrieu-Ponel V, Gambin T, Gandouin E, Médail F, Pavon D, Ponel P, Morhange C (2012) Vegetation dynamics during the early to mid-Holocene transition in NW Malta, human impact versus climatic forcing. Veget Hist Archaeobot 22:367-380

Dolatkhahi M, Yousofi M, Asri Y (2009) Floristic studies of Parishan Wetland and its surroundings in Fars province. Iran $\mathbf{J}$ Biol $1: 35-46$

Eastwood WJ, Roberts N, Lamb HF (1998) Palaeoecological and archaeological evidence for human occupance in southwest Turkey: the Beyşehir occupation phase. Anatol Stud 48:69-86

Fader M, Von Bloh W, Shi S, Bondeau A, Cramer W (2015) Modelling Mediterranean agro-ecosystems by including agricultural trees in the LPJmL model. Geosci Model Dev Discuss 8:4,997-5,040. doi:10.5194/gmdd-8-4997-2015

Florenzano A (2013) Evoluzione di un paesaggio mediterraneo nella ricostruzione archeoambientale di siti lucani: evolution of a Mediterranean landscape as shown by the archaeo-environmental reconstruction of Lucanian sites. PhD Dessertation, Università degli Studi di Modena e Reggio Emilia, Modena

Frahm J-P (2001) Biologie der Moose. Spektrum, Heidelberg

Frey W, Kürschner H (1989) Die Vegetation im Vorderen Orient: Erläuterungen zur Karte A VI 1: Vorderer Orient. Vegetation des Tübinger Atlas des Vorderen Orients Reihe A. Ludwig Reichert, Wiesbaden

Ghazanfar SA (2007) Flora of the Sultanate of Oman, vol. 2: Crassulaceae-Apiaceae. Meise National Botanical Garden (Belgium), Meise

Ghazanfar SA, Fishers M (1998) Vegetation of the Arabian Peninsula. Geobotany 25. Kluwer, Dordrecht

Ghirshman R, Ghirshman T, Haeny G, Hardy AP, Jacquet J, Walker Ghirshman J (1956) Fouilles de Châpour, Bîchâpour: vol. II: Les mosaïques Sassanides. Étude Numismatique par John Walker. Librairie Orientaliste Paul Geuthner, Paris

Ghirshman R, Ghirshman T, Hardy AP (1971) Fouilles de Châpour, Bîchâpour: vol I. Librairie orientaliste Paul Geuthner, Paris

Grimm EC (2004, 2005) TILIA and TGView software. Ver 2.0.2. Illinois State University, Springfield

Haas JN (1996) Neorhabdocoela oocytes-palaeoecological indicators found in pollen preparations from Holocene freshwater lake sediments. Rev Palaeobot Palynol 91:371-382

Hallock RT (1978) Selected Fortification Texts. Cahiers de la Délégation Archéologique Française en Iran 8:109-136

Hardion L, Verlaque R, Saltonstall K, Leriche A, Vila B (2014) Origin of the invasive Arundo donax (Poaceae): a trans-Asian expedition in herbaria. Ann Bot 114:455-462

Harris I, Jones PD, Osborn TJ, Lister DH (2013) Updated highresolution grids of monthly climatic observations-the CRU TS3.10 Dataset. Int J Climatol 34:623-642

Hejabri Nobari A, Khatib Shahidi H, Rezaei MH (2009) Systematic Survey of Tale Jeidun in Kazeroun. Antiquity 83. Available at http://www.antiquity.ac.uk/projgall/rezaei320/

Hinz W, Koch H (1987) Elamisches Wörterbuch II. Archäologische Mitteilungen aus Iran, Ergänzungsband 17. Reimer, Berlin

Jones M, Djamali M, Holmes J, Weeks L, Leng M, Lashkari A, Alamdari K, Noorollahi D, Thomas L, Metcalfe SE (2015) Human impact on the hydroenvironment of Lake Parishan, SW Iran, through the late Holocene. Holocene (in press)

Le Strange G (1905) The land of the Eastern Caliphates, Cambridge geographical series. The University Presse, Cambridge

Manafzadeh S, Salvo G, Conti E (2013) A tale of migrations from east to west: the Irano-Turanian floristic region as a source of Mediterranean xerophytes. J Biogeogr 41:366-379 
Mercuri AM, Bandini Mazzanti M, Florenzano A, Montecchi MC, Rattighieri E (2013) Olea, Juglans and Castanea: the OJC group as pollen evidence of the development of human-induced environments in the Italian peninsula. Quat Int 303:24-42

Miehe G, Miehe S, Schlütz F, Kaiser K, Duo L (2006) Palaeoecological and experimental evidence of former forests and woodlands in the treeless desert pastures of Southern Tibet (Lhasa, A.R. Xizang, China). Palaeogeogr Palaeoclimatol Palaeoecol 242:54-67

Migliore J, Baumel A, Juin M, Médail F (2012) From Mediterranean shores to central Saharan mountains: key phylogeographical insights from the genus Myrtus. J Biogeogr 39: 942-956

Moore PD, Webb JA, Collinson ME (1991) Pollen analysis, 2nd edn. Blackwell, Oxford

Murray E (1968) Oleaceae. In: Rechinger K-H (ed) Flora Iranica, No. 52. Akademische Druck- und Verlagsanstalt, Graz

Newton C, Terral J-F, Ivorra S (2006) The Egyptian olive (Olea europaea subsp. europaea) in the later first millennium BC: origins and history using the morphometric analysis of olive stones. Antiquity 80:405-414

Pickering H, Patzelt A (2008) Field guide to the wild plants of Oman. Kew Publishing, Royal Botanical Garden, Kew

Pourasghar F, Tozuka T, Jahanbakhsh S, Sari Sarraf B, Ghaemi H, Yamagate $\mathrm{T}$ (2012) The internannual precipitation variability in the southern part of Iran as linked to large-scale climate modes. Clim Dyn 39:2,329-2,341

R Development Core Team (2011) R: a language and environment for statistical computing. R Foundation for Statistical Computing, Vienna. http://www.r-project.org

Rechinger K-H (1966) Sapindaceae. In Rechinger K-H (ed) Flora Iranica, No. 38. Akademische Druck- und Verlagsanstalt, Graz

Reille M (1992) Pollen et spores d'Europe et d'Afrique du Nord. Laboratoire de botanique historique et de palynologie, Marseille

Reille M (1995) Pollen et spores d'Europe et d'Afrique du Nord. Supplément 1. Laboratoire de botanique historique et de palynologie, Marseille

Reille M (1998) Pollen et spores d'Europe et d'Afrique du Nord. Supplément 2. Laboratoire de botanique historique et de palynologie, Marseille

Reimer PJ, Baillie MGL, Bard E et al (2009) IntCal09 and Marine09 radiocarbon age calibration curves, 0-50000 years cal BP. Radiocarbon 51:1,111-1,150

Renard M (2014) Les environnements végétaux et agricoles en Crète de 3200 à 2600 cal BP (1200 à 700 BC): étude multidisciplinaire de la série sédimentaire de Phaistos. MSc thesis, Aix-Marseille Université, Aix-en-Provence/Marseille

Riedl H (1968) Pinaceae. In Rechinger K-H (ed) Flora Iranica, No. 14. Akademische Druck- und Verlagsanstalt, Graz
Rull V, López-Sáez JA, Vegas-Vilarrrúbia T (2008) Contribution of non-pollen palynomorphs to the paleolimnological study of a high-altitude Andean lake (Laguna Verde Alta, Venezuela). J Paleolimnol 40:399-411

Sabeti H (1976) Forests, trees, and shrubs of Iran. Iran University of Science and Technology Press, Tehran

Sitch S, Smith B, Prentice C, Arneth A, Bondeau A, Cramer W, Kaplan JO, Levis S, Lucht W, Sykes MT, Thonike K, Venevsky S (2003) Evaluation of ecosystem dynamics, plant geography and terrestrial carbon cycling in the LPJ dynamic global vegetation model. Glob Chang Biol 9:161-185

Stevens LR, Wright HE, Ito E (2001) Proposed changes in seasonality of climate during the Lateglacial and Holocene at Lake Zeribar, Iran. Holocene 11:747-755

Strabo J (1928) Geography, Vol. 5, Books 10-12. Loeb Classical Library 211. H. L. Jones (translation). Harvard University Press, London

Strabo J (1930) Geography, Vol. 7, Books 15-16. Loeb Classical Library 241. H. L. Jones (translation). Harvard University Press, London

Stuiver M, Reimer PJ (1993) Extended ${ }^{14} \mathrm{C}$ database and revised CALIB radiocarbon calibration program. Radiocarbon 35:215-230

Sumner WM (1977) Early settlements in Fars province, Iran. In: Levine LD, Young TC Jr (eds) Mountains and Lowlands: essays in the archaeology of greater Mesopotamia. Malibu, Undena, pp 291-305

Tavernier J (2007) Iranica in the Achaemenid Period (cal 550-330 BC): Lexicon of Old Iranian Proper Names and Loanword Attested in Non-Iranian Texts. Orientalia Lovaniensia Analecta 158. Peeters Publishers, Leuven

UNDP/GEF (2008) Lake Parishan habitat mapping studies. Conservation of Iranian Wetland Project. Iran Department of Environment

UNDP/GEF (2010). In: Moser M (ed) Lake Parishan a concise baseline report, Conservation of Iranian Wetland Project. Iran Department of Environment

Van Zeist W, Bottema S (1991) Late Quaternary Vegetation of the Near East. Beihefte zum Tübinger Atlas des Vorderen Orients: Reihe A, Naturwissenschaften 18. Reichert, Wiesbaden

Vermoere M, Vanhecke L, Waelkens M, Smets E (2003) Modern and ancient olive stands near Sagalassos (south-west Turkey) and reconstruction of the ancient agricultural landscape in two valleys. Glob Ecol Biogeogr 12:217-235

Weeks LR, Alizadeh K, Niakan L, Alamdari K, Khosrowzadeh A, McCall B, Zeidi M (2006) The Neolithic settlement of highland SW Iran: new evidence from the Mamasani District. Iran 44:1-31

Winbow C (2008) The native plants of Oman, an introduction. The Environment Society of Oman, Ruwi

Zohary D, Hopf M (1994) Domestication of plants in the Old World. Clarendon Press, Oxford 